\title{
Operations of Street Food Vendors and Their Impact on Sustainable Life in Rural Nigeria
}

\author{
Richardson Kojo Edeme PhD \\ Senior Lecturer \\ Department of Economics, University of Nigeria, Nsukka \\ Enugu State, Nigeria \\ E-Mail: richard.edeme@unn.edu.ng \\ Tel: +2348035813888 \\ Nkalu, C. Nkalu (corresponding author) \\ Lecturer \\ Department of Economics, University of Nigeria, Nsukka \\ Enugu State, Nigeria \\ E-Mail(s): nelson.nkalu@unn.edu.ng or nkaluconnection@gmail.com \\ Phone: +2348066884155
}

Received: November 8, 2018

Accepted: November 11, 2018

Online Published: November 17, 2018

\begin{abstract}
In recent times, street food vending has become source of livelihood to some urban dwellers and has offered economic benefits to vendors and nutritious foods for the urban dwellers, especially in developing countries. The aim of this study is to investigate the operations and existence of street food vending in Nsukka urban area and examine its effects on sustainable life.. Demographic profiles of vendors, their food safety knowledge, constraints in proper handling practices, the emergence of street food vending, its socioeconomic impact, nature and problems facing street food vendors and their impact on sustainable life were assessed using a closed ended questionnaire. It was found that street food vendors have existed in Nsukka urban area overtime and their emergence was consequent upon the quest for a better life. Also, street food vending has impacted positively on sustainable life in the area through being a source of employment and provision of essential services to the dwellers.
\end{abstract}

Keywords: Street food vendors, Sustainable life, Urban area, Nigeria.

\section{Introduction}

Over time, the sound performance of most developed economies has been attributed to the existence of a vibrant informal sector. The informal sector comprises of some elements such as street retailers, hair salons, mechanic shops, car wash shops, tailor and seamstress shops, the food vendors amongst others. At the apex of these informal sectors lies one of the main stabilizer, street vending. The immense contribution of street food vendors to the growth of the informal sector and the economy at large is not surprising, given the increasing need for highly placed consumer goods which is consequent upon the increasing growth of the world's population, especially in the developing countries (Mcroman, 2007). In Asia, street food vending has been fundamental part of its culinary culture for centuries and they are still seen in great numbers around massive markets in every major city from Shanghai to Hanoi (Hodge, 2014). In Nigeria and Nsukka Urban in particular, street food vending dates back to the 
colonial era, during the period of trade-by-barter when farmers and other individuals move from house to house in search of whom to exchange their farm produce with.

The Food and Agricultural Organization (FAO) of the United Nations defines street foods as ready-to-eat foods and beverages prepared and/or sold by vendors and hawkers especially in streets and other similar public places (FAO report, 1989). The central characteristic of street foods in this definition is location, namely that they are sold on the street. There are three additional distinguishing characteristics of street foods, these are: $(i)$ food prepared in small or cottage-scale factories and brought to the street food stall for sale; (ii) food prepared at the home of the vendor and brought to the street food stall for sale; and (iii) food prepared and sold at the street food stall. According to Escalante de Cruz (2005), there are three main categories of street food vendors, namely 'mobile' vendors, 'semimobile' vendors, who may be stationary or move from one site to another and 'stationary' vendors who sell their food at the same site each day.

Though studies like Betsey (2010) and Hodge (2014) have argued that street food vendors contribute to the development of the informal sector and the economy at large through their linkages with the formal sector, creation of jobs and generation of revenue to local governments with particular reference to Nsukka Local Government Area, thereby contributing to sustainable life through addition of vibrancy to urban life, others argue that some of these street food vendors do more harm to sustainable life than they help to improve it because they harbor potentially hazardous food held at unsafe temperatures, lack proper equipment to maintain food at the required temperatures, expose their food to unsanitary conditions including unclean food equipment, exhibit inadequate protection of food and make use of unapproved food equipment. As in many developing countries, there is need for a policy decision to allow people to earn their living from street food vending in areas under their jurisdiction. Before such a decision can be taken, however, three questions should be considered. First of all, do the activities of these vendors pose a health threat or not? Secondly, what are the opinions of the customers of these street food vendors? And thirdly, is the income earned by the street vendor the main source of their household's income or is it an additional income? Providing answers to these questions form the basis of this study.

2. Review of Literature

In 2011, a study on the effectiveness of food safety training program to street food vendors was conducted by a group of researchers of the University of Public Health Yangon, Myanmar. They examined the comparative study of vendors' knowledge, attitude and practice (K, A, P) scores before and after the food safety training intervention. In the post intervention, the improvement of knowledge, attitude scores found higher; however no significant improvement in practice was found (Maung et.al, 2012). This study concluded that the food safety training program improved food safety Knowledge and Attitude only. Therefore, it suggested that health educations as well as supportive measures such as financial assistance, continuous monitoring, etc. are necessary to improve the vendors' food safety practices and personal hygiene. In managing street foods business, authority concerned may choose one of the following governance steps such as (1) repression or eviction for hawkers' encroachment on the crowded streets-side (2) temporary approval within the limited timeframe (with or without registration fees, within or without zoning area) and (3) the official recognition of the street foods existence and the protecting the selling right of hawkers (at public place) along with the corrective rules to be abided by vendors. Rane (2011) mentioned that Malaysia, Philippines and India are the three countries which have regulations for protecting street vendors. India and Thailand have developed hygienic practices for street vendors so as to upgrade hygiene and quality of street foods (Dawson, 1996). A range of personal, social, and environmental factors influence food handlers practices, and thus these factors need to be addressed in order to change food handlers' behavior (Gul, 2012). A year after an FAOsupported street foods quality improvement campaign, food vendors in one area of Bangkok announced that sales were up 20 percent (FAO, 2002).It shows the necessity to assist the improvement of street foods quality, from controlling perspective. Authority must elucidate a policy aimed at assisting, controlling and maintaining the street food sector (WHO, 1997) it can be achieved through better communication with vendors.

Sustainability means capacity to maintain some entity, outcome, or process over time. Theories of sustainability attempt to prioritize and integrate social responses to environmental and cultural problems. In its increasingly common use, the concept of sustainability frames the ways in which environmental problems jeopardize the conditions of healthy economic, ecological, and social systems. Sustainability illuminates the mutual effects between environmental degradation caused by human activities and the perils to human systems presented by global environmental problems. The concept of sustainability thus raises a starkly basic question: can human activity successfully maintain itself and its goals without exhausting the resources on which it depends? Asking that question directs attention toward the planetary impact of human activity and its durability over time. The broad concept of sustainability has caught the attention of policy makers and citizens of the world. Much of what the term means today is considerably different from what it conveyed a decade ago. As the broad concept of sustainability has evolved, so too have several of its derivatives: sustainable communities, livable communities, and sustainable cities. 
As Beatley and Manning (1997) point out, "there is a general sense that sustainability is a good thing (and that being unsustainable is a bad thing), but will we know it when we see it?" As a matter of practice, as originally envisioned, the concept of sustainable life was derived in an attempt to account for a large number and variety of environmental and interpersonal impacts of economic growth, broadly defined, not comfortably accommodated by neoclassical economic theory or practice.

Kidd (2013) argues that there are at least six different historical intellectual strains of thought that underlie the contemporary concepts of sustainability, each with its own articulation of particularly important foundational issues. He discussed the "ecological/carrying capacity" root, the "natural resource/environment" root. The "biosphere" root, the "critique-of-technology" root and the "ecodevelopment" root (Kidd 1992). Beck J. Brown and colleagues suggest that contemporary usage, the term sustainability has some six different definitions that relate to "sustainable biological resource use," "sustainable agriculture," "carrying capacity," "sustainable energy," "sustainable society and economy," and "sustainable development" (Brown et al. 1987, 713-719). Each of these intellectual roots and definitions suggests its own set of yardsticks that could be used to measure how seriously a city takes sustainability, and to some degree each can be found in sustainability efforts across cities. Sustainable living is a lifestyle that attempts to reduce an individual's or society's use of the earth's natural resources and personal resources. Whether and the extent to which a particular city's initiatives are built on the base of any one set or combination of definitions is determined by a variety or local social and political factors. In short, the seriousness of a city's commitment to sustainability is ultimately determined by the nature of the local governance regime.

\section{Materials and Method}

The design for the study is descriptive survey. It is considered appropriate in carrying out this study because it facilitates the collection of data systematically from a sample of the population, The population of the study consists of street food vendors in Nsukka Local Government Areas of Enugu State. Available records from the National population Commission shows that Nsukka population is around 309,448 for both sexes. The estimated number of food vendors operating around the area at about 186. The probability sampling method was employed. However, the simple random method will be employed to select respondent from within the Nsukka Urban Areas. This technique is chosen for it easy understanding and coverage of the study area and for precise and consistent results.

The sample size was determined using the Yaro Yamen formula stated as.

$$
\mathbf{n}=\frac{\mathrm{N}}{\mathbf{1}+\mathrm{N}(\mathbf{u})^{2}}
$$

However, sixty (60) respondents were interviewed across Nsukka Urban Area.Information were collected from various sources such as street food vendors, patronizers of street food vendors and other dwellers of the study area to make review of the socioeconomic cum environmental impact of the activities of Street Food Vendors. The collected data were examined during and after collection. Only fully answered sheets were entered in computer for analysis. SPSS Statistical package for Social Science, version 20 was used to carry out the analysis. Simple descriptive analysis was employed to analyze frequency, percentage and standard deviation. Face to face interviews were carried out to get in depth knowledge.

4. Results and Discussion

The demographic data of the respondent reveal that $50 \%$ are male while female is $50 \%$. In all, that $51.9 \%$ were less than 30 years, and those of age group 30-39 years formed 44.2\% and 40-49 years formed $3.8 \%$ of the respondents..6 respondents $(11.5 \%)$ had first school leaving certificate as their highest attained level of formal education, 22 (42.3\%) respondents had senior secondary school certificate, another $22(42.3 \%)$ respondents were graduates, 2 respondents had no formal education. In all, the analysis reveal that, there were $33(63.5 \%)$ single respondents and $19(36.5 \%)$ married respondents. In t6erms of household size, the analysis shows that, $4(7.7 \%)$ respondents were husbands, $12(23.1 \%)$ were wives, $34(65.4 \%)$ are sons/daughters while there were $2(3.8 \%)$ others. Households with 5 members and below were 25 forming $48.1 \%$ of the respondents, households with 6 to 10 members were 24 (46.2\%), households with 11 to 15 members were $2(3.8 \%)$ and one of the respondents had a household of 15 members. $4(7.7 \%)$ respondents earn less than ten thousand naira, $23(44.2 \%)$ earn between 10,000 and 20,000, 16 $(30.8 \%)$ earn between 21,000 and 30,000, 1 respondent (1.9\%) earns between 31,000 and 40,000, $8(15.4 \%)$ earn 41,000 and above.

Table 1: Visibility of street food vendors

\begin{tabular}{lll}
\hline Variable & No. of Response & Percentage \% \\
\hline Strongly disagree & 6 & 11.5 \\
\hline Disagree & 1 & 1.9 \\
\hline Indecisive & 3 & 5.8 \\
\hline
\end{tabular}




\begin{tabular}{lll}
\hline Agree & 32 & 61.5 \\
\hline Strongly agree & 10 & 19.2 \\
\hline Total & 52 & 100.0 \\
\hline
\end{tabular}

An assessment of the viability of street food vendors in table $1,11.5 \%$ of the respondents strongly agreed that street food vendors are visible in their locality, $1.9 \%$ disagreed, $5.8 \%$ were indecisive, $61.5 \%$ agreed, while $19.2 \%$ strongly agreed.

Table 2: Number of street food vendors

\begin{tabular}{lll}
\hline Variable & No. of Response & Percentage \% \\
\hline $0-5$ & 18 & 34.6 \\
\hline $6-10$ & 14 & 26.9 \\
\hline $11-15$ & 6 & 11.5 \\
\hline $16-20$ & 5 & 9.6 \\
\hline above 20 & 9 & 17.3 \\
\hline Total & 52 & 100.0 \\
\hline
\end{tabular}

In table 2, 34.6\% respondents say that less than 5 street vendors were visible in their localities, $26.9 \%$ say that 6 to 10 food vendors were visible in their locality, $11.5 \%$ say 11 to 15 were visible, $9.6 \%$ say 16 to 20 were visible and $17.3 \%$ say there are more than 20 street vendors in their localities.

Table 3: Patronage of street food vendors

\begin{tabular}{lll}
\hline Variable & No. of Response & Percentage $\%$ \\
\hline Often & 13 & 25.0 \\
\hline very often & 12 & 23.1 \\
\hline Rarely & 20 & 38.5 \\
\hline very rarely & 6 & 11.5 \\
\hline Indecisive & 1 & 1.9 \\
\hline Total & 52 & 100.0 \\
\hline
\end{tabular}

From the table above, $25 \%$ of the respondents often patronize street food vendors, $23.1 \%$ patronize them very often, $38.5 \%$ rarely do, $11.5 \%$ very rarely do, $1.9 \%$ were indecisive.

Table 4: Satisfaction from street food vendors

\begin{tabular}{lll}
\hline Variable & No. of Response & Percentage $\%$ \\
\hline to no extent & 2 & 3.8 \\
\hline to a little extent & 11 & 21.2 \\
\hline to some extent & 25 & 48.1 \\
\hline to a great extent & 12 & 23.1 \\
\hline to a very great extent & 2 & 3.8 \\
\hline Total & 52 & 100.0 \\
\hline
\end{tabular}

From the table $4,3.8 \%$ of the respondents do not derive satisfaction from street food vendors, $21.2 \%$ derived satisfaction to a little extent, $48.1 \%$ do to some extent, $23.1 \%$ does to a great extent, and $3.8 \%$ does to a very great extent.

Table 5: Most prominent type of street food vendors

\begin{tabular}{lll}
\hline Variable & No. of Response & Percentage \% \\
\hline Stationary & 8 & 15.4 \\
\hline Non-stationary & 8 & 15.4 \\
\hline Both & 34 & 65.4 \\
\hline Others & 2 & 3.8 \\
\hline Total & 52 & 100.0 \\
\hline
\end{tabular}

From the table 5, result shows that $15.4 \%$ of the respondents said that stationary street food vendors were more prominent in their locality, $15.4 \%$ also said that non-stationary street food vendors were more prominent in their locality, $65.4 \%$ say both are prominent while $3.8 \%$ say others types of vendors are more prominent. From the 
results, it is observed that about $3.8 \%$ of the respondents strongly disagreed; another $3.8 \%$ agreed; $5.8 \%$ were indecisive; $51.9 \%$ agreed while $34.6 \%$ strongly agreed that street food vendors have been in existence in Nsukka urban. From the results obtained, it is observed that about $3.8 \%$ of the respondents strongly disagreed; $7.7 \%$ disagreed; $17.3 \%$ were indecisive; $48.1 \%$ agreed while $23.1 \%$ strongly agreed that the emergence of street food vendors in Nsukka urban was consequent upon the quest for a better life. From the results obtained, it is observed that about $5.8 \%$ of the respondents strongly disagreed; $11.5 \%$ disagreed; $9.6 \%$ were indecisive; $51.9 \%$ agreed while $21.2 \%$ strongly agreed that poor access to credit facilities engendered the choice of street food vendors over a standard eatery in Nsukka urban. It is observed that about $7.7 \%$ of the respondents strongly disagreed; $21.2 \%$ disagreed; $15.4 \%$ were indecisive; $48.1 \%$ agreed while $7.7 \%$ strongly agreed that street food vendors in Nsukka urban area have basic educational qualification (i.e., First School Leaving Certificate). From the results obtained, it is observed that about $9.6 \%$ of the respondents strongly disagreed; $50.0 \%$ disagreed; $13.5 \%$ were indecisive; $23.1 \%$ agreed while $3.8 \%$ strongly agreed that street food vendors in Nsukka urban area are relatively high income earners. As evidenced in the results, about $1.9 \%$ of the respondents strongly disagreed; $17.3 \%$ disagreed; $1.9 \%$ were indecisive; $65.4 \%$ agreed while $13.5 \%$ strongly agreed that the activities of street food vendors in Nsukka urban area have reduced unemployment. Also, about $11.5 \%$ of the respondents strongly disagreed; $40.4 \%$ disagreed; $25.0 \%$ were indecisive; $19.2 \%$ agreed while $3.8 \%$ strongly agreed that street food vendors in Nsukka urban area have access to good housing facilities. Beside, $3.8 \%$ of the respondents strongly disagreed; $26.9 \%$ disagreed; $19.2 \%$ were indecisive; $44.2 \%$ agreed while $5.8 \%$ strongly agreed that street food vendors in Nsukka urban area contribute to environmental hazard. Result also reveal that $3.8 \%$ of the respondents strongly disagreed; $21.2 \%$ disagreed; $17.3 \%$ were indecisive; $51.9 \%$ agreed while $5.8 \%$ strongly agreed that there is high sense of insecurity among street food vendors in Nsukka urban area. None of the respondents opted for strongly disagree; about $9.6 \%$ disagreed; $17.3 \%$ were indecisive; $55.8 \%$ agreed while $17.3 \%$ strongly agreed that inadequate communication and technical skills affect street food vendors in Nsukka urban area. As revealed in the results, about $3.8 \%$ of the respondents strongly disagreed; $13.5 \%$ disagreed; $1.9 \%$ were indecisive; $57.7 \%$ agreed while $23.1 \%$ strongly agreed that government policies like imposition of taxes, fines and rates affect street food vendors in Nsukka urban area. As revealed in the results, none of the respondents opted for strongly disagreed; about $7.7 \%$ disagreed; $3.8 \%$ were indecisive; $57.7 \%$ agreed while $30.8 \%$ strongly agreed that the street food vendors in Nsukka urban area are faced with limited space and facilities. None of the respondents opted for strongly disagreed; about $7.7 \%$ disagreed; $7.7 \%$ were indecisive; $55.8 \%$ agreed while $28.8 \%$ strongly agreed that site allocation poses a challenge to street food vendors in Nsukka urban area.

Overall, the result indicate that none of the respondents opted for strongly disagreed; about 5.8\% disagreed; none of the respondents were indecisive; about $78.8 \%$ agreed while $15.4 \%$ strongly agreed that street food vendors were well appreciated by consumers for their availability at the right place and time. About 5.8\% of the respondents strongly disagreed; $13.5 \%$ disagreed; $17.3 \%$ were indecisive; about $50.0 \%$ agreed while $13.5 \%$ strongly agreed that most cases of food poisoning emanated from the activities of street food vendors in Nsukka urban area. Moreover, none of the respondents opted for strongly disagreed; about 5.8\% disagreed; $13.5 \%$ were indecisive; $71.2 \%$ agreed while $9.6 \%$ strongly agreed that food vending provides essential services to many of the urban inhabitants. Also, none of the respondents opted for strongly disagreed; about $11.5 \%$ disagreed; $11.5 \%$ were indecisive; $51.9 \%$ agreed while $25.0 \%$ strongly agreed that food vending provides cheap food to the people in Nsukka urban area. As shown in the results, about $5.8 \%$ of the respondents strongly disagreed; $13.5 \%$ disagreed; $19.5 \%$ were indecisive; $59.6 \%$ agreed while $1.9 \%$ strongly agreed that food vendors provide low quality food to the people in Nsukka urban area. About $5.8 \%$ of the respondents strongly disagreed; $21.2 \%$ disagreed; $15.4 \%$ were indecisive; $42.3 \%$ agreed while $15.4 \%$ strongly agreed that food vending is a viable alternative to youth empowerment in Nsukka urban area.

From the analysis, it was discovered that street food vendors has been a source of livelihood that has existed in Nsukka urban over time and has contributed immensely to sustainable life in the area though not without some negative implications. This was evidenced in the responses of the respondents. According to the analysis, it was observed that the quest for a better life has been the major driving force for the emergence of street food vendors in Nsukka urban area. On the socioeconomic impact of the existence of food vendors, the findings revealed that food vending has aided unemployment reduction in the area of study and invariably, has affected the income distribution positively though being a major contributed to environmental and health challenges in the area. This was attributed to environmental littering and poor hygiene practices among the food vendors. Furthermore, the findings revealed that government policies and limited space and facilities were the major problem faced by food vendors in Nsukka urban. This is consequent upon the fact that there exist series of government taxes, fines and levies meted upon these food vendors, this scenario is not surprising given that Nsukka urban is the headquarters of Nsukka Local Government Area. The large hectares of land occupied by the University of Nigeria located in the area to a great extent reduced the mass of land available in the area, and this contributed to the poor availability of space for the 
operations of these food vendors. Finally, the findings further revealed that street food vendors have impacted on sustainable life through their provision of essential services and acting as a viable alternative for youth empowerment in the area though contributing to food poisoning through the provision of low quality food to residents.

\section{Conclusion}

This study was undertaken to empirically evaluate the operations of street food vendors and their impact on sustainable life in Nsukka urban area. This study was specifically carried out to examine the emergence of street food vendors, to determine the socioeconomic impact, to examine the nature and problems affecting their operations and to investigate the overall impact of street food vendors on sustainable life in the area of coverage. To achieve the objectives of the study, questionnaires were administered to various respondents in the area of study and direct interview method was also adopted and it was found that street food vending was observed to have been in existence within the area of study and its emergence was consequent upon the quest for a better life with a statistically higher percentage of response of about $51.9 \%$ and $48.1 \%$ respectively. The activities of street food vendors was found to have positive impact on as employment generation while their activities had a negative impact on their earnings, housing and contribution to environmental within the area of study with about $65.4 \%$ positive response to reduction in unemployment, $40.4 \%$ negative response, $44.2 \%$ positive responses to housing and environmental hazards respectively. Insecurity, inadequate communication and technical skills, harsh government policies, site allocation and limited space and facilities inhibit the activities of street food vendors in the area of study. Findings show that an average of $55.78 \%$ of the respondents agreed to the above mentioned assertion. Averagely, about $61.05 \%$ of the respondents opined that street food vendors has positive impact on sustainable life while about $54.8 \%$ were of the opinion that street food vendors impacts negatively on sustainable life given that their activities pose some health challenges. Given that most of the socioeconomic indicators of sustainable life, through the activities of street food vendors were negative, government should establish a department of city development committees to help engender positive impact of street food vending and further make it a more viable means of livelihood. Since government policies through levies and fines and poor/limited space were the major problems faced by food vendors, special local monitoring team should be set up in the Nsukka urban area to ascertain the legality or otherwise of these collections in order to reduce the financial burden on these food vendors and help improve their performances. Given that the activities of some of the street food vendors pose some health challenges, orientation should be organized for these food vendors to sensitize them on some standard hygienic practices.

\section{References}

Artemis, P.S \&. Bhat, R. V (2000). Street foods. Basel: Karger Publishers

Beneria, L. \& Floro, M.S. (2006). Labor market informalisation, gender and social protection:

Reflections

on poor urban households in Bolivia, Ecuador and Thailand, in Razavi S.and

Charmes, J. (1998). Women working in the informal sector in Africa: New methods and new United Nations Statistics Division.

Chukuezi, C.O.(2010). Entrepreneurs of the streets: Socio-economic features of street food Vending in Owerri, Nigeria, European Journal of Social Sciences, 14(2), 183-188

Dardano, C. (2003). Caribbean regional working group on street food vendors, Report of FAO,PAHO and BNSI. Accessed from: http://ftp.fao.org/es/esn/food/carribean_report.pdf,

Food and Agriculture Organization (FAO) (2007). School kids and street food, spotlight Magazine. Agriculture and Consumer Protection Department, United Nations. Accessed from http://www.fao.org/AG/magazine/0702sp1.htm International Labour Organization (ILO) (2002). Men and women in the informal economy.

Accessed from http://www.ilo.org/public/english/employment/gems/download/women.pdf

Manning, C (1993). International experiences of informal sector activity and the lessons South for Transformation,

Accessed

Africa. http://www.transformation.ukzn.ac.za/archive/tran022/tran022006.pdf

Mukhola, M.S. (2007). Guidelines for an environmental education training programme for street Food vendors in Polokwane City. Accessed from: http://etd.rau.ac.za/theses/submitted/etd-03132007140510/restricted/last.pdf

Muzaffar, A.T., I. Huq \& Mallik, B. A. (2009). Entrepreneurs of the streets: An analytical work on the street food vendors of Dhaka City. International Journal of Business and Management, 4(2), 80-88

Ruel, M., C. Levin, S. Morris, D. Maxwell, M. Armar-Klemusu \& Ahiadeke, C. (1999). Working women in an urban setting traders, vendors and food security in Accra. World Development Report,

Sardier, M.(2003). Women's socio-economic roles in the urban Sahel: A preliminary study of Bamako Niamey, Journal of Political Ecology, 10(1), 47-56. 
Sethuraman, S.V. (1981). The urban informal sector in developing countries: Employment, $\quad$ Poverty and environment. Geneva: International Labour Office.

Tinker, I.(1997). Street foods: Urban food and employment in developing countries. New York: Oxford University Press

UNECA (United Nations Economic Commission for Africa), (2008). Achieving gender equality and women's empowerment in Africa, progress Report. The African Development Forum (ADF VI) 19-21 November, Addis Ababa. Accessed from: http://www.uneca.org/adfvi/documents/ADFVI_Progress_Report_ENG.

Verick, S.(2006). The impact of globalization on the informal sector in Africa, Addis Ababa: Accessed from: http://www.iza.org/conference_files/worldb2006/verick_s872.pdf

World Health Organization (2006). Street food vending in the region. Food safety challenges. Safety Newsletter, (2)

Winarno, F.G \& Allain, A. (1991). Street foods in developing countries: Lessons from Asia. $\quad$ Rome: Food and Agriculture Organization (FAO). Accessed from: http://www.fao.org/docrep/U3550T/U3550T00.htm, World Bank (2001). World Development Report: Attacking poverty. Washington D.C.

\section{Copyrights}

Copyright for this article is retained by the author(s), with first publication rights granted to the journal.

This is an open-access article distributed under the terms and conditions of the Creative Commons Attribution license (http://creativecommons.org/licenses/by/4.0/) 